УДК $82-93(=1-81)$

\title{
Soviet and Post-Soviet periods \\ in the History of Children's Literature \\ in the Languages of the Indigenous Peoples \\ of the North, Siberia and the Far East
}

\author{
Vladimir S. Luzan* \\ Siberian Federal University \\ 79 Svobodny, Krasnoyarsk, 660041, Russia
}

Received 20.02.2016, received in revised form 14.05.2016, accepted 29.08.2016

\begin{abstract}
The article attempts to identify relevant methodological and practical approaches to the research of Soviet and post-Soviet periods in the history of children's literature in the languages of the indigenous minorities of the North, Siberia and the Far East and its role in preserving these peoples' original habitat and sustainable socio-cultural development. The article states that the analysis of classical and modern Russian research of this subject reveals the writers' inadequate attention to children's literature as an integral part of literature in general. In conclusion the author outlines general conclusions and probable trends in the development of children's literature in the indigenous minorities' languages in modern socio-cultural situation.

The research is performed within the frame of the project "Creation of a corpus of texts for children in native languages (Evenk, Nenets, Nganasan, Dolgan) as a way of preserving the unique cultural heritage of the indigenous minorities of Krasnoyarsk Krai" supported by the Krasnoyarsk Krai Science Foundation.
\end{abstract}

Keywords: language, children's literature, culture, indigenous minorities, self-identification, cultural development, cultural processes.

DOI: 10.17516/1997-1370-2016-9-9-2060-2070.

Research area: theory and history of culture.

\section{Introduction}

In conditions of a new state formation and search for national identity of the Russian people as a whole and the peoples of the Russian Federation, in particular, the Russian society is going through a controversial period in their own development: on the one hand, they face a difficult process of socio-economic and spiritual uplift of some individual ethnic groups as an integral part of a unified state, on the other hand, adoption of new priorities and ideas takes place together with overcoming of outdated lifestyle elements and social principles. Simultaneously there is a return to ancient, original traditions, rituals and customs, revival of old beliefs inherent to each ethnic group. A special role in these processes,

(c) Siberian Federal University. All rights reserved

* Corresponding author E-mail address: vladimir_luzan@list.ru 
undoubtedly, belongs to children's literature as it largely determines the image of a socializing personality and paves the way for the cultural codes and symbols translated in the future.

In this regard the relevance of the research of Soviet and post-Soviet periods in the history of children's literature in the languages of the indigenous minorities of the North, Siberia and the Far East is due to several factors:

- as an independent socio-cultural phenomenon children's literature in the indigenous peoples' languages originates exactly in the Soviet period as they enter the space of writing and print culture on the basis of national folklore;

- in the Soviet and post-Soviet periods children's literature in the indigenous peoples' languages has its own traditions distinguishing it from literature in the languages of other peoples living in the Russian Federation.

Besides, the Framework of the State cultural policy of the Russian Federation approved by the Decree of the President of the Russian Federation No. 808 dated 24.12.2014 (Osnovy gosudarstvennoi...) identifies a number of key tasks making the research of children's literature in the languages of the indigenous minorities of the North pertinent:

1. Preservation of the heritage of the Russian culture and all Russian peoples' cultures as a universal value determining the Russian people's identity and vitality. The cultural heritage also impliesitsnon-material part:languages, traditions, customs, dialects, folklore, and traditional ways of life and ideas of the indigenous peoples' world organization.

Thus, cultural heritage is a focal point of all spiritual, moral, historical, and cultural experience of Russian civilization and peoples, constituting its basis. Therefore, it is the basis and source of the country's development, maintenance of its unity and identity.
2. Support of domestic literature, revival of interest in reading, creating the conditions for the book publishing industry development, providing the citizens with the access to Russian classical and modern literature, works of literature in the languages of the peoples of Russia.

Historically, literature holds a special place in spiritual and cultural life of Russia. It is literature, and especially children's literature, that forms moral ideals, passes on the people's rich spiritual experience to new generations. Consequently, the support of modern literary creation, book and literary magazines publishing is one of the most important tasks of the state cultural policy.

3. Development of Russian and national cultures of the peoples of Russia, providing facilities for professional creative activity, the citizens' creative initiative, maintenance, creation and development of necessary infrastructure. The society's ability to develop is directly dependent on the level of the development of culture, professional art, the citizens' participation in various forms of cultural activities.

Thus, the tasks mentioned once again justify the relevance of the research of literature in the indigenous peoples' languages in general and children's literature in particular. At the same time an issue of the research is the fact that children's literature in the indigenous peoples' languages is one of the youngest and it is not formed yet because the majority of the indigenous peoples did not have their own written languages till the XX century. In this regard the subject of the research in Russian scientific practice has been literature as such, as a rule, and primarily literature of the peoples of Russia with earlier written language and culture that is studied more thoroughly (the peoples of the North Caucasus and the indigenous peoples of Central Russia who do not belong to the category of "indigenous peoples").

In its turn, literature in the indigenous peoples' languages is relatively young children's 
literature. The period of its existence in print culture is only a little more than a century. Thus, the influence of literary traditions, established art models weighs upon writers.

Another solid problem in the research of children's literature in the indigenous peoples' languages is a serious danger of its complete unification: stories, characters, genres and styles can lose their originality; however, this does not happen due to a new round of the indigenous peoples' national identity formation.

The most important feature of children's literature in the languages of the indigenous minorities of the North is undoubtedly its direct dependence on folklore. Yet, the printed word during the formation of this genre as a selfsufficient one is not so much strong, especially in literatures that emerged on the basis of the borrowed alphabet. In this context the oral word, associated with myth and ritual and to which the life of the family, generation and the whole nation is subject to, has a substantially large effect, especially in the process of upbringing children. As a result, folklore works and folklorized literature are still a significant part of the publications for children. Besides, the first publications, that the researchers classify as children's literature, were also folklore ones.

Therefore, one of the most important objectives of a children's writer is to support a child's national attitude and pass on spiritual values common to all mankind to him/her. National identity is a positive experience for a child; thus, children's books in the native and Russian languages must meet the highest requirements of art, be relevant to socialize the readers as valuable members of micro and macro society.

\section{Methodology of the research}

A theoretical and methodological basis of the research are the general scientific principle of historicism and the historical-comparative method, the comprehensive approach and a systematic analysis of the periodicals and literary sources on various aspects of formation of children's literature in the indigenous minorities' languages.

In addition, the methodological basis is constituted of the conceptual provisions outlined in the works of interdisciplinary, philosophical and cultural character (A.F. Losev, E.V. Il'enkov, et al.); theory and history of literature (A.N. Veselovskiy, M.M. Bakhtin, D.S. Likhachev, V.I. Sorokin, Iu.M. Lotman, G.N. Ionin); ethnography, ethnology (V.G. Bogoraz, G.M. Vasilevich, V.V. Podmaskin, et al.).

The research methods are the following one: theoretical (analysis of cultural, philosophical, literary, ethnographic, linguistic, psychological, art literature), empirical (guides, documentation analysis), interdisciplinary problem analysis (involving data of ethno-philology, ethnography, ethno-pedagogy, art history, ethno-psychology).

\section{State of knowledge}

Regarding the Soviet period of the research of children's literature in the languages of the indigenous minorities of the North, the following Russian writers and researchers of the literature of the North should be undoubtedly mentioned: V.G. Bogoraz-Tan, I. Vdovin, G.D. Verbov, M. Voskoboinikov, N. Gudkov, I. Kratt, G. Mel'nikov, G. Menovshchikov, V. Naumova, S.N. Stebnitskiy, M.A. Sergeev, P. Skorik, et al.

Among Soviet ethnographers, linguists, writers, translators, who introduced the indigenous peoples' creative work to Soviet culture, are S. Bytovoi, N. Gessen, G. Gora, P. Daletskiy, A. Smolian, L. Popova, G. Semenov, A. Chivilikhin, Iu. Shestakova, et al.

The feature of the indigenous peoples' children's literature is that for some writers the Russian language became not only the language 
of international communication but also the native literary language. G. Khodzher, a Nanaian novelist, A. Pichkov, a Nenets poet, wrote in Russian, some writers translated their works into Russian (for example, Iu. Rytkheu, a Chukcha, Iu. Shestalov, a Mansi, V. Sangi, a Nivkh). All this resulted in the fact that the first conference of the indigenous peoples' writers was held in Leningrad in March 1961, the conference considering the pressing issues of literature and folklore development. The meeting of the Union of Writers of the RSFSR held in December 1965 was also devoted to this topic.

Some problems of the development of children's literature in the indigenous peoples' languages are analyzed in the works by such modern Russian writers as I.N. Arzamastseva, E.V. Bulgakov, G.N. Ionin, N.P. Koptseva, V.P. Krivonogov, O.K. Lagunova, V.V. Ogryzko, A.A. Petrov, R.T. Sakova, Iu.G. Hazankovich, et al.

There are a number of dissertation researches in domestic scientific practice which focus on various aspects of the phenomenon of children's literature in the indigenous peoples' languages. These are first and foremost the works by O.N. Al'shevskaia, M.M. Kerimova, I.V. Lizunova, L.V. Oganezova, et al.

Dwelling on children's literature one cannot ignore the contemporary researchers' growing interest to the issues of increasing diversification of various theories, their focus being the issues of the future of the book, its transformation, place and role in modern media space (I.E. Barenbaum, R.S. Giliarevskiy, K.M. Sukhorukov, Iu.N. Stoliarov, A.V. Sokolov) as well as modern issues of book publishing in general (S.Iu. Zorina, A.M. Il'nitskiy, L.A. Kirillova, S.A. Kondratov, B.V. Lenskiy, M.F. Nenashev, N.A. Seliverstova, et al.).

A special role in the research of the problems of the development of children's literature in the indigenous peoples' languages in modern socio- cultural space is taken by the works on various issues of existence and specifics of the book publishing institutions' integration in modern media space, as children's literature, like any other sort of literature, is doomed to regress in its development without such integration. As a result, the researchers reveal the change in theoretical approaches to understanding of such a basic concept as "book", reveal new concepts of "electronic book", "electronic edition" (V.A. Glukhov, O.L. Lavrik, S.N. Liutov, L.A. Kharitonova); trace the specific features of the contemporary media space formation (I.V. Lizunova, O.V. Makeeva, S.S. Paichadze, G.B. Parshukova, O.V. Shtoler); determine the impact of web business on the media space expansion (T.D. Rubanova, O.N. Al'shevskaia); emphasize the need for the integration of libraries as specific actors of socio-cultural transformations in contemporary media space (S.D. Borodina, L.I. Gosina, Iu.G. Emanova, L.A. Kozhevnikova, O.L. Lavrik, G B. Parshukova, L.E. Savich, A.V. Sokolov, et al.).

Thus, the range of issues that are the subjects of the research of children's literature in the indigenous peoples' languages has undergone a number of significant changes in the post-Soviet period and is supplemented with completely new aspects that the Soviet period lacked. First of all, the matter is children's literature inclusion into media space.

\section{Results}

It is worth while mentioning the fact that the beginning of national children's literatures, including those in the indigenous peoples' languages, was mainly due to active magazine life both in the Russian Empire and in the USSR times. These were magazines that first began to publish literary works for children, the authors being both the indigenous peoples' representatives and Russian writers engaged in translation. 
In 1898, V.N. Haruzina, a most famous Russian scientist-ethnographer, made a fairytales collection for children "Skazki russkikh inorodtsev" ("Fairy-tales of Russian foreigners") which included the fairy-tales of the Samoyeds, Lapps, Finns, Estonians, Latvians, Mordva, Ostyaks, Bashkirs, Kirghiz, Kalmyks, Kazan, Minusinsk, Abakan Tatars, Buryats, Yakuts, Yukaghirs, Chukchi, Gilyaks, Goldy, Sarts, Kabardians, Chechens, Ingush, Lezghins, Ossetians, Georgians, Imeretians, Armenians and Kurds. Thus, this edition can be considered the first to present children's literature in the indigenous peoples' languages.

In general the 19th century should be considered to be the beginning of systematic collection, study and publication of materials, primarily associated with the names of political exiles (V.G. Bogoraz (Tan), V.I. Iochel'son, L.Ia. Shternberg). The collections of Chukchi, Yukaghir, Gilyatsk (Nivkh) folklore, etc. were published. In this respect, a special role is taken by the fairy-tale genre as it fully reflects the indigenous peoples' work and life in severe nature, their dreams about the victory over the elements and struggle against oppressors, glorifies a human's courage, resourcefulness, and perseverance and expresses people's optimism. In fairy-tales fiction is directly adjacent to reality, household origin; many of them focus on social motives.

The Committee of the Assistance to the North Suburban Nationalities, established under the Central Executive Committee of the USSR (192435) and headed by P.G. Smidovich, provided the minorities with comprehensive assistance in the development of culture in general and literature in particular. The compilation of ABC-books for the indigenous minorities by Soviet linguists and ethnographers is an important milestone of Cultural Revolution. Moreover, specialized educational institutions were opened on the territory of the RSFSR (primarily in Siberia), native languages were created (since 1931 - based on the Latin alphabet; since 1937 - based on the Russian alphabet) during this period.

The first literary works of the indigenous minorities were collected by the students of the Northern Department of Leningrad Oriental Institute. They are namely short stories, essays, folklore records, that were collected in the book for reading in national schools - "O nashei zhizni" ("About Our Life") (1929) and literary materials in student collections "Taiga and Tundra" (192833).

The literatures of the Khanty, Mansi, Nenets, Evenks, Evens, Nanais, Udege, Chukchi, Koryaks as self-sufficient phenomena had been formed by the end of the 30-s on the basis of national written languages. The development of these literatures is largely due to the influence of Russian literature, which helped the writers of the North to portray dramatic changes in their peoples' lives and was a school of ideology and artistic mastery for them. The indigenous minorities' works of literature of this period are distinguished by a deep connection with the motives and images of northern folklore, dynamism of the plot, richness of the narrative in accurate details, a picturesque depiction of the world in motion, introduction of the dialogue, and a laconic and aphoristic style.

In his article "Problemy sokhraneniia i razvitiia iazykov i literatur malochislennykh narodov Severa" ("Problems of maintenance and development of languages and literatures of the minorities of the North") A.A. Petrov, doctor of philology, reasonably stated that a special role in the development of children's literature in the indigenous peoples' languages was played by the establishment of the Institute of the Peoples of the North of the Central Executive Committee of the USSR in Leningrad in 1930, its traditions being continued today by the Institute of the Peoples of the North of Herzen University. Research 
and Development Association, established at the Institute of the Peoples of the North, had developed the project of the indigenous peoples' alphabet by the end of 1930 already, the project was approved in the beginning of 1931 by the All-Union Committee of the New (Latinized) Alphabet at the Presidium of the Council of Nationalities of the Central Executive Committee of the USSR and the Board of People's Commissariat for Education of the RSFSR.

In January 1932 the First All-Russian conference on the development of the indigenous minorities' languages and written languages was held. It approved the proposal of Research and Development Association of the Institute of the Peoples of the North about practical possibility and expediency of creation of writing in the following languages: 1) Sami (Lapp, Laplander); 2) Nenets (Samoyed); 3) Mansi (Vogul); 4) Khanty (Ostyak); 5) Selkup (Ostyako-Samoyed); 6) Ket (Yenisei); 7) Evenk (Tungus); 8) Even (Lamut); 9) Nanai (Goldy); 10) Udei; 11) Luora-Vetlansk (Chukotka); 12) Nymylan (Koryak); Nivkh (Gilyak); Yuit (Eskimo). It also approved the basic principles of terminology and spelling of the Nordic languages (Petrov 2011, p. 37).

The post-war period of the formation of children's literature in the indigenous minorities' languages is distinguished by the growth of the authors' creative activity, emergence of new names. The writers master new themes and genres. The circle of written literatures broadens. Thus, they start publishing the works of literature by the Selkup, Ulchi, Eskimos, Nivkh, Yukaghir peoples. The struggle for a new man who is free from the burden of old beliefs and habits often becomes a fundamental conflict in the indigenous minorities' literature. Portraying a spiritual character of the resurgent peoples' sons and daughters, a complex process of breaking the old psychology, the characters' formation, the writers strive to reveal the deeper inner world of the contemporaries.

In general, the state cultural policy in the USSR was aimed at the national writers' comprehensive support. The reports about competitions, reviews of the latest publications, essays about the writers from the republics, articles on translation issues and other similar materials were published on the pages of "adult" press and "Detskaya Literatura" ("Children's Literature") journal. At the same time a number of contradictions can be singled out in the policy implemented: the largest publishing houses were focused on publishing books in the national language. Yet, it was easier for the authors, who were schooled by the masters of the Russian classics, to write in Russian sometimes, especially when the topic demanded modern vocabulary. As a result, this led to the dominance of Russian creativity among national writers, which, of course, was reflected in children's literature.

It is possible to judge about the achievements of national children's literatures in the USSR by one of the latest publications, the publication being the collection of poetic translations of Iu.I. Kushak's "Dom druzei" ("The House of Friends" (1985) that included the poems by Antonina Kymytval', a Chukchi poetess.

The last All-Union seminar of the critics of children's and juvenile literature, authors and publishers took place in Yalta in spring of 1991, after which there happened the well-known geopolitical events causing the collapse of the USSR.

A new round of the return to native language and native literature started after the transition to the post-Soviet cultural space after long decades when the writers of the peoples of Russia faced a difficult choice, the choice being whether to write in their native language or in Russian. However, publication of children's literature faced new socio-economic conditions, which resulted in 
significant changes, first of all having deprived the book publishing of the state support.

As rightly noted by the authors of the article "Izdanie knig dlia detei v Sibiri i na Dal'nem Vostoke (1990-e gg.)" ("Publishing of the books for children in Siberia and the Far East (1990-s)", children's literature in the Soviet period was in very short supply as the demand for it was satisfied only by $30-35 \%$. In the first half of the 1980 -s about 2 thousand titles of books for children and young people were published in the country (Lizunova, Bulgakova 2013, p. 66). This made no more than $4-5 \%$ of the total book products output; children's literature in the indigenous peoples' languages constituted even a much smaller part.

Besides, the authors of the above mentioned article reasonably state that by 1991 the number of publications dropped to 1610 titles, then the years of instability began and only from 1996 the indices of publications of books for children started growing and by the beginning of the next decade they twice exceeded the indices of the Soviet period and amounted to 4123 titles (Ibid., p. 67).

At the same time there was a collapsing downfall of the children's books editions against the background of the number of titles growth. A sharp (8 times) decline in annual editions (from 365 million copies in 1991 to 47 million copies in 1997) was stabilized at the level of 54-57 million copies only by the beginning of 2000 , the edition of children's books in the indigenous peoples' languages was a few thousand copies at best.

The growth of children's literature production indices in the first decades of the 20th century (in 2000-2003 an average publication rate reached a million copies) indicated the initial stage of overcoming the crisis in the field of children's books publishing. However, this does not concern children's literature in the indigenous minorities' languages.

Thus, the post-Soviet period in the development of children's literature in the languages of the indigenous minorities of the North faces the crisis of book publishing but not that of authorship. The situation in Siberia and the Far East turned out to be particularly controversial in comparison with other regions. Children's literature occupies an isolated position in most publishing houses, and there are no specialized publishers, working exclusively in the children's literature market and especially the market of children's literature in the languages of the indigenous minorities of the North, in Siberia and the Far East at all.

\section{Conclusions}

The analysis of Soviet and post-Soviet periods in the history of children's literature in the languages of the indigenous minorities of the North, Siberia and the Far East leads to the following conclusions:

- Measures of state protectionism in the field of publication of children's literature in the indigenous peoples' languages that are reflected in the Principles of the State Cultural Policy of the Russian Federation have become particularly urgent in the current socio-economic conditions;

- The Russian language, which is a language of international communication, and the peoples' common historical destiny with close interaction of their cultures unite children's literature of the indigenous peoples of the Russian Federation;

- Russian folklorists, ethnographers and writers played a crucial role in the initial stage of the formation of the majority of children's literatures in the languages of the indigenous peoples of the North;

- National folklore still serves the basis for the development of children's literature in the indigenous minorities' languages;

- At present all children's literatures in the languages of the indigenous minorities of the North have entered the writing-and-printing stage of culture development; 
- A new round of the indigenous peoples' return to their native language and native literature is observed in modern realities;

- Modern writers, creating in their native language, base on already established national literary traditions, including the traditions in children's literature;

- Development of children's literature in the languages of the indigenous minorities of the North will be largely determined by its representation in the Internet telecommunication network and possibilities of its reading on modern gadgets that is evidenced by the functioning of corresponding Internet resources;

- Development of children's literature in the indigenous minorities' languages as an integral part of Russian culture should become one of the most important tasks of the state cultural policy of the Russian Federation.

\section{References}

Al'shevskaia, O.N. (2010). Knizhnaia torgovlia v Sibiri v kontse XX-nachale XXv. Dissertatsiia kandidata istoricheskikh nauk [Book Trade in Siberia in the Late XX-Early XXI Century. Thesis of the Candidate of Historical Sciences]. Novosibirsk.

Antoshin, K.F. (1987). Vechno zhivye istoki: O fol'klore i molodoi sovetskoi literature narodov i narodnostei Sibiri, Krainego Severa i Dal'nego Vostoka [Forever Live Origins: On Folklore and Young Soviet Literature of the Peoples and Nationalities of Siberia, the Far North and the Far East). Krasnoyarsk: Izdatel'stvo Krasnoiarskogo universiteta.

Arzamastseva, I.N. (2013). Detskaia literature [Children's Literature]. Moscow, Academy.

Baldanov, S.Zh. (2004). Sibir' - edinoe fol'klorno-literaturnoe polietnicheskoe prostranstvo [Siberia - a Single Folklore-and-Literature Multiethnic Space. Yakutsk, 155-162.

Burykin, A.A. (2002). Nekotorye problem sotsiokul'turnogo razvitiia malochislennykh narodov Severa RF v svete gendernogo podkhoda [Some Problems of Socio-Cultural Development of the Northern Indigenous Minorities of the Russian Federation in the Light of the Gender Approach], In Rasy i Narody [Races and Peoples], 28, 188-213.

Ionin, G.N. (2003). Literatura - chast' dukhovnoi kul'tury naroda: problemy sokhraneniia i razvitiia [Literature - a Part of the People's Spiritual Culture: Problems of Maintenance and Development]. Tvorcheskii potentsial narodov Severa $v$ XXI veke [Creative Potential of the Peoples of the North in the XXI Century], 120-124.

Kerimova, M.M. (2013). Stanovlenie i razvitie rossiiskoi etnografii poslednikh desiatiletii XIX - pervoi treti XX v. (na osnove izucheniia nauchnogo naslediia sem'I Kharuzinykh [Formation and Development of Russian Ethnography of the Last Decades of the XIX-Beginning of the XX Century (On the Basis of Scientific Heritage of the Kharuziny Family). Moscow.

Khasankovich, Iu.G. (2009a). Fol'klorno-epicheskie traditsii v proze malochislennykh narodov Severa [The Folklore-and-Epic Traditions in the Prose of the Indigenous Peoples of the North]. Novosibirsk, Izdatel'stvo Sibirskogo otdeleniia Rossiiskoi akademii nauk.

Khasankovich, Iu.G. (2009b). Puti i puty kritiki: O sovremennom sostoianii izucheniia literature malochislennykh narodov Severa i Sibiri [Ways and Fetters of Criticism: On the Present State of the Study of the Literatures of the Small Peoples of the North and Siberia], In Siberian philological journal, 3, 78-83.

Khasankovich, Iu.G. (2009c). Proza malochislennykh narodov Sibiri, Severa i Dal'nego Vostoka v kritike 1970-1990-kh gg. [The Prose of the Indigenous Peoples of Siberia, North and the Far East in the Criticism of the 1970s-1990s], In Bulletin of the Chita State University, 3 (54), 185-190. 
Khristoforov, V. (2009). Snegov polet gorizontalen: Redaktsiia gazety "Literaturnaia Rossiia" prodolzhaet izdavat' tsikl knig o pis'mennykh traditsiiakh korennykh malochislennykh narodov Severa [A Horizontal Fly of Snows: the "Literary Russia" Newspaper Office Keeps on Publishing the Series of Books about the Written Traditions of the Indigenous Peoples of the North], In Mir Severa [The World of The North], 1, 69-73.

Kistova, A.V., Pimenova, N.N., Zamaraeva, Ju.S., Reznikova, K.V. (2014). Research Possibilities for Studying the Indicators of Quality of Life of Indigenous Peoples of the North (Based on the Study of Indigenous Peoples of the North of Russia), In Life Science Journal, 11(6s), 593-600.

Koptseva, N.P. (2014). Expert Analysis of the Main Trends of Northern Siberia's Indigenous Small-Numbered Peoples Economic Development, In Economic Annals-XXI, 11-12, 93-96.

Koptseva, N.P. (2015). The Current Economic Situation in Taymyr (the Siberian Arctic) and the Prospects of Indigenous Peoples' Traditional Economy, In Economic Annals-XXI, 9-10, 95-97.

Koptseva, N.P., Kirko, V.I. (2014a). The Information Basis for Formation of Positive Ethnic Identities in the Process of Acculturation of Indigenous Peoples of the Arctic Siberia (Krasnoyarsk, Russia, In Life Science Journal, 11(8), 479-483.

Koptseva, N.P., Kirko, V.I. (2014b). Processes of Acculturation Khakases (Indigenous People of Southern Siberia), Living Outside of the Khakassia in the Urban and Student Environment, In American Journal of Applied Sciences, 11 (12), 1969-1975.

Koptseva, N.P., Kirko, V.I. (2014c). Ethic Identification of Indigenous People of the Siberian Arctic, In American Journal of Applied Sciences, 11 (12), 1969, 1969-1975.

Koptseva, N.P., Kirko V.I. (2014d). Post-Soviet Practice of Preserving Ethnocultural Identity of Indigenous Peoples of the North and Siberia in Krasnoyarsk Region of the Russian Federation, In Life Science Journal, 11(7), 180-185.

Koptseva, N.P., Kirko, V.I. (2014e). Specificity of Ethnogeny Indigenous Peoples by Central Siberia in the Transition from the Traditional Type of Society to Modern Society, In Life Science Journal, 11(7), 409-413.

Koptseva, N.P., Kirko, V.I. (2014f). Modeling of the Basic Processes and Traditional Way of Life of Indigenous Peoples of Krasnoyarsk region (Eastern Siberia), In Life Science Journal, 11(10), 489-494.

Koptseva, N.P., Kirko, V.I. (2014g). Modern Specificity of Legal Regulation of Cultural Development of the Indigenous Peoples of the Arctic Siberia under the Global Transformations, In Life Science Journal, 11(9), 314-319.

Koptseva, N.P., Kirko, V.I. (2015). The Impact of Global Transformations on the Processes of Regional and Ethnic Identity of Indigenous Peoples of Siberian Arctic, In Mediterranean Journal of Social Sciences, 6 (3), 217-224.

Koptseva, N.P., Reznikova, K.V. (2015). Refinement of the Causes of Ethnic Migration North Selkups Based on the Historical Memory of Indigenous Ethnic Groups Turukhansk District of Krasnoyarsk Krai, In Bylye gody, 4 (38), 1028-1038.

Korennye malochislennye narody Taimyra: traditsii, byt, kul'tura: rekomendatel'nyi ukazatel' literatury [The Indigenous Minorities of the Taymyr Peninsula: Traditions, Everyday Life, Culture: Advisory Literature Index] (2005). Dudinka.

Krivonogov, V.P. (2008a). Tofalary: tri shaga v budushchee [The Tofalars: Three Steps into the Future]. Krasnoyarsk, Krasnoyarsk State Pedagogical University named after V.P. Astafiev. 
Krivonogov, V.P. (2008b). Chulymtsy v nachale XXI veka [The Chulyms at the Beginning of the XXI Century]. Krasnoyarsk, Krasnoyarsk State Pedagogical University named after V.P. Astafiev.

Lagunova, O.K. (2010). Nauchnye versii fenomena literaturnogo tvorchestva korennykh malochislennykh narodov Severa Zapadnoi Sibiri [Scientific Versions of the Phenomenon of the Literary Creativity of the Indigenous Peoples of the North of Western Siberia], In Ot teksta k kontekstu [From Text to Context], 9, 143-148.

Libakova, N.M., Sitnikova, A.A., Sertakova, E.A., Kolesnik, M.A., Ilbeykina, M.I. (2014). Interaction of the Yakut Ethnicity and Biological Systems in the Territory of the Sakha Republic (Hordogoy Settlement, Suntarsky District) and Krasnoyarsk Krai (Essey Settlement, Evenks District), In Life Science Journal, 11 (6s), 585-592.

Lizunova, I.V., Bulgakova, E.V. (2013). Izdanie knig dlia detei v Sibiri i na Dal'nem Vostoke (1990-e gg.) [Publishing of Books for Children in Siberia and the Far East (the 1990-s)], In Gumanitarnye nauki v Sibiri [The Humanities in Siberia], 3, 66-70.

Literatura narodov Severa [The Literature of the Peoples of the North] (2002). Saint Petersburg, Publishing House of Herzen University.

Literatura narodov Severa, Sibiri i Dal'nego Vostoka: Sovremennye podkhody v teorii i metodike issledovaniia i prepodavaniia [The literature of the Peoples of the North, Siberia and the Far East: Current Approaches in Theory and Methodology of Research and Teaching]. Real'nost' etnosa [The Reality of Ethnos], 2007, 236-298.

Oganezova, L.V. (2004). Tvorchestvo Dzhansi Kimonko kak osnovopolozhnika udegeiskoi literatury: Dissertatsiia kandidata filologicheskikh nauk [Creativity of Dzhhansi Kimonko as the Udege Literature Founder: Thesis of Candidate of Philology]. Saint-Petersburg.

Ogryzko, V.V. (1998). Pisateli i literatory malochislennykh narodov Severa i Dal'nego Vostoka: bibliograficheskii spravochnik [Writers and Literary Men of the Indigenous Peoples of the North and the Far East: Bibliographical Reference Book]. Moscow, Literaturnaia Rossiia.

Ogryzko, V.V. (2013). Litsa i liki: literature malochislennykh narodov Severa i Dal'nego Vostoka [Faces and Images: The Literature of the Indigenous Peoples of the North and the Far East]. Moscow, Literaturnaia Rossiia.

Osnovy gosudarstvennoi kul'turnoi politiki Rossiiskoi Federatsii, utverzhdennye Ukazom Prezidenta Rossiiskoi Federatsii ot 24.12.2014 № 808 [The Foundations of State Cultural Policy of the Russian Federation approved by the Decree of the President of the Russian Federation No. 808 dated 24.12.2014]. Available at: http://mkrf.ru/upload/mkrf/mkdocs2016/OSNOVI-PRINT.NEW.indd.pdf

Petrov, A.A. (2011). Problemy sokhraneniia i razvitiia iazykov i literatur malochislennykh narodov Severa [The Problems of Maintenance and Development of Languages and Literatures of the Indigenous Peoples of the North], In Universum: Bulletin of the Herzen University, 11, 37-40.

Portal "Literatura malochislennykh narodov Severa" [The "Literature of the Indigenous Peoples of the North" Portal]. Available at: http://www.sakhamemory.ru/liter/Main.aspx

Poshataeva, A.V. (1988). Literatury narodov Severa: Istoki. Stanovlenie. Razvitie [Literatures of the Peoples of the North: Origins. Formation. Development]. Moscow, Nauka.

Poshataeva, A.V. (1993). Mifologiia i opyt pisatelei Severa [Mythology and Experience of the Writers of the North]. Sposobnost' $k$ dialogu [Ability to the Dialogue]. Moscow, 122-155. 
Sakova, R.T.(1985). Fol'klor i literatura narodov Sibiri [Folklore and Literature of the Peoples of Siberia]. Krasnoyarsk.

Shprygov, Iu.M. (2005). Stanovlenie i razvitie literatury korennykh malochislennykh narodov Severo-Vostoka (kak dukhovno-intellektual'nyi protsess) [Formation and Development of the Literature of the Indigenous Peoples of the North-East (as a Spiritual and Intellectual Process)]. Intellektual'nye resursy Severo-Vostoka Rossii [Intellectual Resources of the North-East of Russia], 272-274.

Voprosy iazyka i literatury narodov Sibiri [Issues of Language and Literature of the Peoples of Siberia] (1974). Novosibirsk.

Vzaimodeistvie literatur narodov Sibiri i Dal'nego Vostoka [Interaction of Literatures of the Peoples of Siberia and the Far East]. (1983). Novosibirsk, Nauka, Sibirskoe otdelenie.

Zamarayeva, Y.S., Kistova, A.V., Pimenova, N.N., Seredkina, N.N. (2015). Taymyr Reindeer Herding as a Branch of the Economy and a Fundamental Social Identification Practice for Indigenous Peoples of the Siberian Arctic, In Mediterranean Journal of Social Sciences, 6 (3), 225-232.

\title{
Советский и постсоветский периоды
}

\section{в истории детской литературы}

на языках коренных

малочисленных народов Севера,

Сибири и Дальнего Востока

\author{
В.С. Лузан \\ Сибирский федеральный университет \\ Россия, 660041, Красноярск, пр. Свободньий, 79
}

\begin{abstract}
В статье предпринята попытка раскрыть актуальные методологические и практические подходы к исследованию советского и постсоветского периодов в истории становления детской литературы на языках коренных малочисленных народов Севера, Сибири и Дальнего Востока и ее роли в сохранении исконной среды обитания и устойчивого сочиально-культурного развития данных народов. Отмечается, что анализ классических и современных отечественных исследований данного предмета выявляет недостаточное внимание авторов к детской литературе как неотъемлемой составляющей литературы в изелом. В заключении автором обозначены общие выводы и вероятные тенденции развития детской литературы на языках коренных малочисленных народов в современной социально-культурной ситуации.

Работа выполнена в связи с проектом «Создание корпуса текстов для детей на родных языках (эвенкийский, ненеикий, нганасанский, долганский) как способ сохранения уникального культурного наследия коренных малочисленных народов Красноярского края», поддержанным Красноярским краевым фондом науки.
\end{abstract}

Ключевые слова: язык, детская литература, культура, коренные малочисленные народы, самоидентификаиия, культурное развитие, культурные процессы.

Научная специальность: 24.00.01 - теория и история культуры. 